\title{
Recognition and sensing of anions through synergistic effects using simple benzimidazolium-urea receptors
}

\author{
DONG ZhiYun \& GAO GuoHua* \\ Shanghai Key Laboratory of Green Chemistry and Chemical Processes, Department of Chemistry, East China Normal University, Shanghai \\ 200062, China
}

Received October 26, 2011; accepted December 30, 2011; published online February 25, 2012

\begin{abstract}
Benzimidazolium-based receptors 1-3 were designed and synthesized. On the basis of fluorescence, UV-Vis, and ${ }^{1} \mathrm{H}$ NMR spectroscopic studies, and X-ray single crystal structure analysis, it was confirmed that the receptor $\mathbf{1}$ displays strong $(\mathrm{C}-\mathrm{H})^{+} \ldots \mathrm{X}$, $\mathrm{N}-\mathrm{H} \cdots \mathrm{X}$ hydrogen bonds and charge-charge interactions with anions. More importantly, these investigations demonstrated that the charged $(\mathrm{C}-\mathrm{H})^{+}$benzimidazolium and urea moieties play a synergistic role in anion recognition.
\end{abstract}

anion recognition, benzimidazolium, urea, synergistic effects, hydrogen bond

Citation: Dong Z Y, Gao G H. Recognition and sensing of anions through synergistic effects using simple benzimidazolium-urea receptors. Chin Sci Bull, 2012, 57: 1266-1274, doi: 10.1007/s11434-012-5033-2

Design and synthesis of fluorescent receptors for selective sensing and binding of anionic species are of great interest in host-guest chemistry [1-7], largely because anions are ubiquitous in both chemical and biochemical processes. In particular, phosphate anions and their derivatives are important in signal transduction and energy storage in biological systems $[8,9]$. Fluoride anions play an important role in dental care and the treatment of osteoporosis [10-12]. Carboxylates are critical components in numerous metabolic processes such as the citric acid and glyoxylate cycles [13-15]. They also play an important role in the biosynthesis of intermediates [16].

Various receptors that can recognize anions have been demonstrated. In general, most of these receptors use amide [17-19], pyrrole [20-22], urea/thiourea [23-27], or hydroxyl [28-30] groups, as hydrogen bonding synthons. Coordination of electron-deficient Lewis acid species by orbital overlap has also been used in the binding of anions [31-33]. In recent years, receptors with positively charged moieties such as ammonium [34-37], guanidinium [38,39], pyridinium [40-44], and imidazolium/benzimidazolium [45-54]

*Corresponding author (email: ghgao@chem.ecnu.edu.cn) have also received considerable attention. Imidazolium/ benzimidazolium subunits bind anions through both chargecharge interactions and unconventional ionic $(\mathrm{C}-\mathrm{H})^{+} \ldots \mathrm{X}(\mathrm{X}$ $\left.=\mathrm{O}, \mathrm{N}, \mathrm{F}^{-}, \mathrm{Cl}^{-}, \mathrm{Br}^{-}, \mathrm{I}^{-}\right)$hydrogen bonds [55,56]. Benzimidazolium subunits are more electron-deficient than imidazolium groups.

The hydrogen bonding of imidazolium ions along with other hydrogen bonding motifs or Lewis acids is a strategy used to design receptors. Ghosh et al. [57,58] reported the binding properties of benzimidazolium-based orthophenylenediamine derivatives towards various anions, and found that the complexes are stabilized by both conventional $(\mathrm{N}-\mathrm{H} \cdots \mathrm{O})$ and unconventional hydrogen bonds $[\mathrm{C}-\mathrm{H} \cdots \mathrm{O}$, $\left.(\mathrm{C}-\mathrm{H})^{+} \cdots \mathrm{X}\right]$, as well as charge-charge interactions. Xu et al. [59] developed a series of asymmetric bidentate receptors containing boronic acid and an imidazolium group as fluorescent receptors for fluoride ions. They found that ortho-directed boron and imidazolium exhibit enhanced fluoride binding. To the best of our knowledge, receptors containing both benzimidazolium and urea binding units have seldom been reported, and the interplay of these two functional groups during anion recognition has not been investigated in detail. In this regard, we designed and synthesized 
three new fluorescent receptors 1-3 (Scheme 1). Receptor $\mathbf{1}$ contains both $(\mathrm{C}-\mathrm{H})^{+}$benzimidazolium and urea groups as binding sites. For comparison, receptor 2 only possesses a $(\mathrm{C}-\mathrm{H})^{+}$benzimidazolium group and receptor $\mathbf{3}$ only has a urea group as binding site, respectively. The binding abilities of receptors 1-3 with anions were evaluated by X-ray single crystal structure analysis, ${ }^{1} \mathrm{H}$ NMR, fluorescence and UV-Vis spectroscopic methods. Receptor 1 shows better recognition ability towards various anions because it has multiple binding sites so it can display strong $(\mathrm{C}-\mathrm{H})^{+} \cdots \mathrm{X}$, and $\mathrm{N}-\mathrm{H} \cdots \mathrm{X}$ hydrogen bonds as well as charge-charge interactions.

\section{Experimental}

\subsection{Materials and instruments}

All commercially available reagents were used without further purification. ${ }^{1} \mathrm{H}$ and ${ }^{13} \mathrm{C}$ NMR spectra were recorded in DMSO- $d_{6}$ using $\mathrm{Me}_{4} \mathrm{Si}$ as an internal standard on a Bruker Avance DRX 500 FT NMR spectrometer operating at 500 $\mathrm{MHz}$ for ${ }^{1} \mathrm{H}$ NMR spectra and $125 \mathrm{MHz}$ for ${ }^{13} \mathrm{C}$ NMR spectra. Mass spectra were acquired using an Agilent ion trap instrument equipped with an ESI source. Fluorescence spectra were obtained on a Hitachi F-4500 fluorescence spectrometer. UV-Vis spectra were measured on a Varian Cary-100 UV spectrophotometer.

\subsection{Synthesis and characterization}

1-Methyl-3-(2-ureidoethyl)-1H-benzimidazolium tetrafluoroborate (1). A solution of $N$-methylbenzimidazole $(0.66 \mathrm{~g}$, $5 \mathrm{mmol})$ and 2-chloroethylurea $(0.74 \mathrm{~g}, 6 \mathrm{mmol})$ in ethanol $(10 \mathrm{~mL})$ was heated under reflux for $72 \mathrm{~h}$ under $\mathrm{N}_{2}$. After the reaction mixture was cooled to room temperature, the white precipitate was collected and dissolved in $\mathrm{H}_{2} \mathrm{O}(25$ $\mathrm{mL})$. Anion exchange was carried out by reaction with $\mathrm{AgBF}_{4}$. The desired product 1 was yielded as a white powder $(0.68 \mathrm{~g}, 45 \%)$. ${ }^{1} \mathrm{H}$ NMR $\left(500 \mathrm{MHz}, \mathrm{DMSO}-d_{6}\right)$ : 3.46-

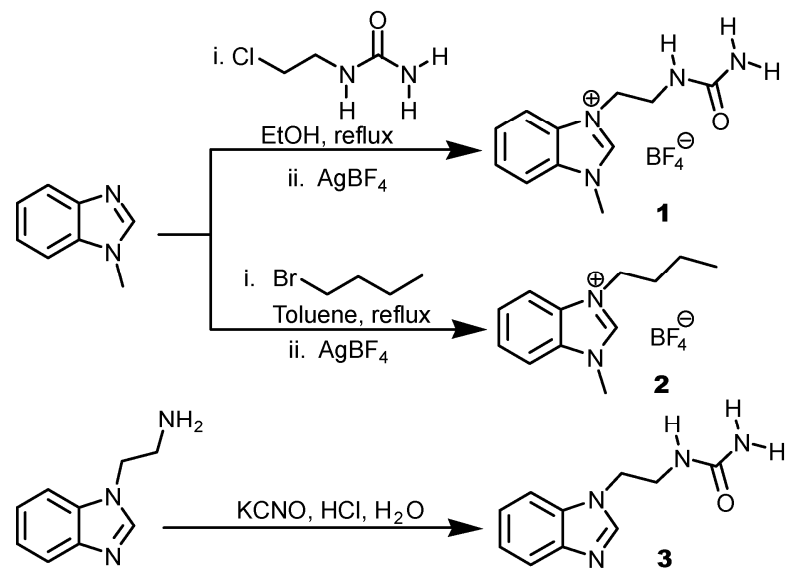

Scheme 1 Procedure used to synthesize anion receptors 1-3.
$3.49(2 \mathrm{H}, \mathrm{m}), 4.09(3 \mathrm{H}, \mathrm{s}), 4.51(2 \mathrm{H}, \mathrm{t}, J=6.0 \mathrm{~Hz}), 5.59$ $(2 \mathrm{H}, \mathrm{s}), 6.24(1 \mathrm{H}, \mathrm{t}, J=6.0 \mathrm{~Hz}), 7.68-7.71(2 \mathrm{H}, \mathrm{m})$, 8.00-8.06 (2H, m), $9.71(1 \mathrm{H}, \mathrm{s}) ;{ }^{13} \mathrm{C} \mathrm{NMR}(125 \mathrm{MHz}$, DMSO- $\left.d_{6}\right): 33.16,38.65,47.27,113.45,113.49$, 125.38, 125.48, 131.29, 131.78, 142.95, 158.67; ESI-MS m/z calcd. for $\mathrm{C}_{11} \mathrm{H}_{15} \mathrm{~N}_{4} \mathrm{O}^{+} 219.1$, found 219.0.

3-Butyl-1-methyl-1H-benzimidazolium tetrafluoroborate (2). A solution of $N$-methylbenzimidazole $(0.66 \mathrm{~g}, 5 \mathrm{mmol})$ and 1-bromobutane $(0.82 \mathrm{~g}, 6 \mathrm{mmol})$ in toluene $(10 \mathrm{~mL})$ was heated under reflux for $11 \mathrm{~h}$ under $\mathrm{N}_{2}$. After the reaction mixture was cooled to room temperature, the white precipitate was collected and crystallized from acetone, then dissolved in $\mathrm{H}_{2} \mathrm{O}(25 \mathrm{~mL})$ and anion exchange was carried out by reaction with $\mathrm{AgBF}_{4}$. The desired product 2 was yielded as a white powder (1.02 g, 79\%). ${ }^{1} \mathrm{H}$ NMR (500 $\left.\mathrm{MHz}, \mathrm{DMSO}-d_{6}\right): 1.72(3 \mathrm{H}, \mathrm{t}, J=7.5 \mathrm{~Hz}), 2.11-2.18(2 \mathrm{H}$, m), 2.65-2.71 (2H, m), $4.88(3 \mathrm{H}, \mathrm{s}), 5.29(2 \mathrm{H}, \mathrm{t}, J=7.0 \mathrm{~Hz})$, 8.47-8.52 (2H, m), 8.81-8.89 (2H, m), $10.54(1 \mathrm{H}, \mathrm{s}) ;{ }^{13} \mathrm{C}$ NMR (125 MHz, DMSO- $\left.d_{6}\right)$ : 13.32, 19.00, 30.58, 33.15, $46.25,113.45,113.53,125.40,125.41,130.94,131.81$, 142.69; ESI-MS $\mathrm{m} / \mathrm{z}$ calcd. for $\mathrm{C}_{12} \mathrm{H}_{17} \mathrm{~N}_{2}{ }^{+} 189.1$, found 189.1.

1-(2-(1H-Benzo $[d]$ imidazol-1-yl)ethyl)urea (3). Potassium cyanate $(0.55 \mathrm{~g}, 6.7 \mathrm{mmol})$ was added to a solution of 2-(1Hbenzo[ $d]$ imidazol-1-yl)ethanamine hydrochloride (1.19 $\mathrm{g}$, $6 \mathrm{mmol})$ in water $(8 \mathrm{~mL})$. The reaction mixture was then stirred at room temperature for $5 \mathrm{~h}$ under $\mathrm{N}_{2}$. The solid was separated by filtration and crystallized from ethanol, yielding the desired product as a light yellow powder $(0.71 \mathrm{~g}$, $58 \%) .{ }^{1} \mathrm{H}$ NMR (500 Hz, DMSO- $\left.d_{6}\right): 3.46(2 \mathrm{H}, \mathrm{t}, J=5.0$ $\mathrm{Hz}), 4.51(2 \mathrm{H}, \mathrm{t}, J=5.0 \mathrm{~Hz}), 5.95(2 \mathrm{H}, \mathrm{s}), 6.83(1 \mathrm{H}, \mathrm{br})$, $7.56-7.61(2 \mathrm{H}, \mathrm{m}), 7.84(1 \mathrm{H}, \mathrm{d}, J=7.6 \mathrm{~Hz}), 8.00(1 \mathrm{H}, \mathrm{d}, J$ $=7.4 \mathrm{~Hz}), 9.41(1 \mathrm{H}, \mathrm{s}) ;{ }^{13} \mathrm{C} \mathrm{NMR}\left(125 \mathrm{MHz}, \mathrm{DMSO}-d_{6}\right)$ : $33.05,42.27,113.33,115.10,125.85,125.15,131.02$, 131.34, 141.98, 171.85. ESI-MS $m / z$ calcd. for $\mathrm{C}_{10} \mathrm{H}_{13} \mathrm{~N}_{4} \mathrm{O}^{+}$ 205.1, found 205.0.

\subsection{General procedure for fluorescence titration}

Stock solutions of the receptors were prepared in HPLC grade acetonitrile and $2 \mathrm{~mL}$ of each receptor solution was added to a cuvette. The solution was irradiated at the selected excitation wavelength. Upon addition of a guest compound (anion) dissolved in acetonitrile, first at intervals of 0.1 equiv. from 0 to 2.0 equiv., then at intervals of 1 equiv. from 3 to 50 equiv., the change in fluorescence emission of the receptor was observed. The corresponding emission values during titration were recorded and used for to determine binding constants. The change in emission in the presence of different equivalents of guest anions was used to produce Stern-Volmer plots.

\subsection{General procedure for UV-Vis titration}

Stock solutions of the receptors were prepared in DMSO 
and $2 \mathrm{~mL}$ of each receptor solution was added to a cuvette. Anionic guests dissolved in DMSO were added to the receptor solution (at intervals of 0.5 equiv. from 0 to 10 equiv., then at intervals of 2 equiv. from 10 to 50 equiv.), and the corresponding absorbance during titration was measured.

\subsection{X-ray structure determination}

X-ray diffraction data from suitable crystals were collected using a Bruker-AXS APEX0-II CCD area detector diffractometer with monochromated Mo K $\alpha$ radiation $(\lambda=0.71069$ $\AA)$. The SHELX programs were used for structure solution and refinement [60].

Crystallographic data for $\mathbf{1}^{+} \cdot \mathrm{Cl}^{-} \cdot 2 \mathrm{H}_{2} \mathrm{O}$. The data was obtained from a crystal that was a colorless block and had approximate dimensions of $0.15 \mathrm{~mm} \times 0.18 \mathrm{~mm} \times 0.36 \mathrm{~mm}$. Triclinic, space group $P_{l}^{-}, a=7.6455$ (3) $\AA, b=10.0400$ (5) $\AA, c=10.8011(5) \AA, \alpha=114.9470(10)^{\circ}, \beta=95.1300(10)^{\circ}$, $\gamma=101.6240(10)^{\circ}, V=721.99(6) \AA^{3}, Z=2, \mathrm{GOF}=1.073$, $R_{1}=0.0324, w R_{2}=0.0876$. Crystallographic data for the structure $\left(\mathbf{1}^{+} \cdot \mathrm{Cl}^{-} \cdot 2 \mathrm{H}_{2} \mathrm{O}\right)$ have been deposited in the Cambridge Crystallographic Data Centre as supplementary publication No. CCDC-819028. These data can be obtained free of the charge from the Cambridge Crystallographic Data Centre via www.ccdc.cam.ac.uk/conts/retrieving.html.

\section{Results and discussion}

\subsection{Design and synthesis of receptors 1-3}

Receptors 1-3 containing different binding subunits were designed and synthesized. Receptors $\mathbf{1}$ and $\mathbf{2}$ were synthesized by the reaction of 2-chloroethylurea or 1-bromobutane with $\mathrm{N}$-methylbenzimidazole followed by anion exchange with $\mathrm{AgBF}_{4}$ in good yield. Receptor 3 was synthesized by reaction of 2-(1H-benzo[d]imidazol-1-yl)ethanamine with potassium cyanate. All of these compounds were characterized by ${ }^{1} \mathrm{H}$ and ${ }^{13} \mathrm{C}$ NMR spectroscopy, and mass spectrometry. The single crystal X-ray structure of $\mathbf{1}$ provided unambiguous structural confirmation.

\subsection{Solid state crystal structure of $\mathrm{1}^{+} \cdot \mathrm{Cl}^{-} \cdot 2 \mathrm{H}_{2} \mathrm{O}$}

Crystals of the chloride salt of $\mathbf{1}$ suitable for single crystal $\mathrm{X}$-ray structure determination were obtained upon slow concentration of the mother liquor at room temperature. The crystal system of $\mathbf{1}^{+} \cdot \mathrm{Cl}^{-} \cdot 2 \mathrm{H}_{2} \mathrm{O}$ is triclinic and the unit cell consists of a benzimidazolium cation, a chloride anion and two water molecules. The molecular structure of $\mathbf{1}^{+} \cdot \mathrm{Cl}^{-}$. $2 \mathrm{H}_{2} \mathrm{O}$ is shown in Figure 1.

The distances between the chloride and $(\mathrm{C}-\mathrm{H})^{+}$benzimidazolium protons is $3.591 \AA(\mathrm{C} 8-\mathrm{H} 8 \mathrm{~A} \cdots \mathrm{Cl} 1=4.221 \AA)$, which is larger than the sum of the van der Waals radius of a $\mathrm{H}$ atom and the ionic radius of a chloride anion (3.14 $\AA$ ). The angle $\mathrm{C} 8-\mathrm{H} 8 \mathrm{~A} \cdots \mathrm{Cl} 1$ is $126.04^{\circ}$, suggesting the ionic

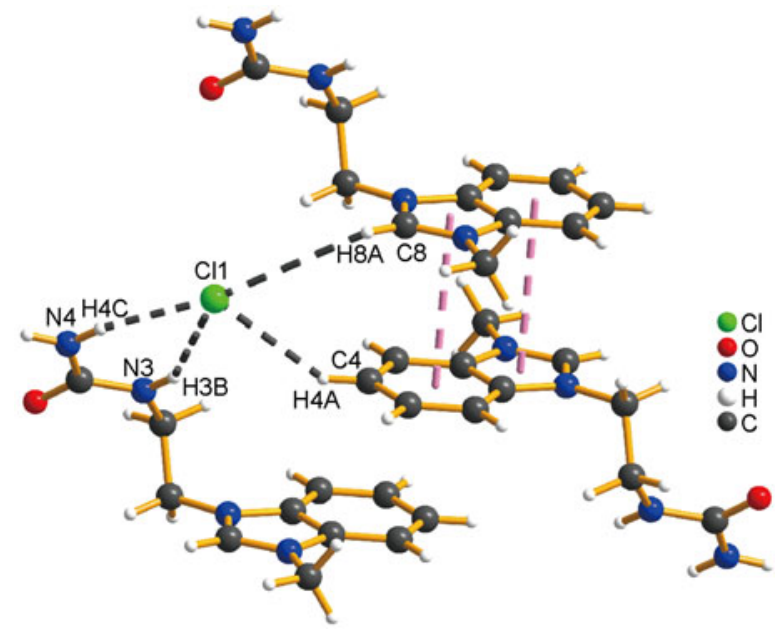

Figure 1 The crystal structure of $\mathbf{1}^{+} \cdot \mathrm{Cl}^{-} \cdot 2 \mathrm{H}_{2} \mathrm{O}(50 \%$ probability thermal ellipsoids) showing $\mathrm{N}-\mathrm{H}^{\cdots} \cdot \mathrm{Cl}^{-}, \mathrm{C}-\mathrm{H}^{\cdots} \cdot \mathrm{Cl}^{-},(\mathrm{C}-\mathrm{H})^{+} \cdots \mathrm{Cl}^{-}$hydrogen bonding and intermolecular $\pi-\pi$ stacking interactions. $\mathrm{H}_{2} \mathrm{O}$ molecules are omitted for clarity.

$(\mathrm{C}-\mathrm{H})^{+}{ }^{\cdots} \mathrm{Cl}^{-}$hydrogen bond is weaker than that observed other receptors [61,62]. Moreover, the crystal structure reveals that the chloride anion forms strong hydrogen bonds with two urea protons ( $\mathrm{H} 3 \mathrm{~B}$, and $\mathrm{H} 4 \mathrm{C})$, as well as forming a hydrogen bond with a proton of the aromatic benzene ring

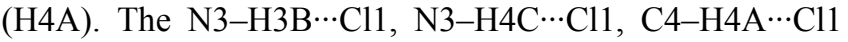
distances are $3.365,3.296$, and $3.666 \AA$, respectively, and bond angles $\mathrm{N} 3-\mathrm{H} 3 \mathrm{~B} \cdots \mathrm{Cl1}$, N4-H4C $\cdots \mathrm{Cl} 1$, and $\mathrm{C} 4-$ $\mathrm{H} 4 \mathrm{~A} \cdots \mathrm{Cl}$ are $151.27^{\circ}, 157.22^{\circ}$, and $146.79^{\circ}$, respectively. There is also an intermolecular $\pi-\pi$ stacking interaction (distance $=3.577 \AA$ ) between imidazolium and benzene rings in the crystal structure.

\subsection{Fluorescence study}

The sensitivity and selectivity of receptors 1-3 towards various anions (including fluoride, chloride, bromide, iodide, acetate, hydrogen sulfate, and dihydrogen phosphate ions as their tetrabutylammonium salts) were evaluated by observing changes in the fluorescence emission spectra of $\mathbf{1}-\mathbf{3}$ in acetonitrile. In the absence of anions, 1 (concentration of $6.0 \times 10^{-6} \mathrm{~mol} / \mathrm{L}$ ) shows a characteristic emission band at $375 \mathrm{~nm}$ when excited at $277 \mathrm{~nm}$. Upon addition of increasing amounts of anions, the intensity of the emission band at $375 \mathrm{~nm}$ gradually decreased without producing any other spectral change (i.e., no spectral shift or formation of a new emission band). This is ascribed to the quenching effect of a photoinduced electron transfer (PET) process from the urea moiety to the charged benzimidazolium ring [13]. Quenching of emission varied between anions, as revealed in the Stern-Volmer plot shown in Figure 2. The nonlinear nature of the curves for $\mathbf{1}$ with dihydrogen phosphate and fluoride suggests interplay of both static and dynamic quenching [63]. Dihydrogen phosphate, fluoride and acetate anions are more basic than the other anions and hence induce stronger 


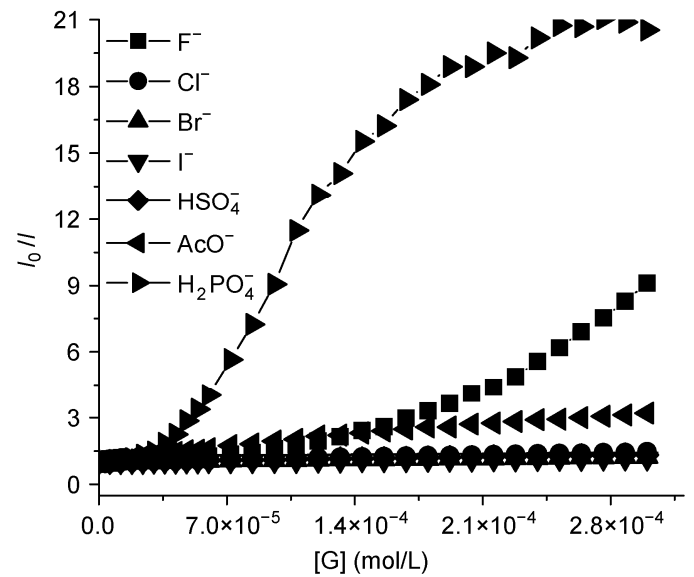

Figure 2 Stern-Volmer plot of 1 measured at $375 \mathrm{~nm}$.

quenching.

As a representative example, the corresponding change in the emission spectra of $\mathbf{1}$ upon gradual addition of fluoride is displayed in Figure 3.

The fluorescence Job plots of receptor 1 (Figure 4) shows that the concentration of the host-guest complex [H-G] approaches a maximum when the molar fraction of guest is 0.5 , which indicates $1: 1$ stoichiometry of the complex with the receptor.

The excited state properties of $\mathbf{2}$ were investigated in the presence of the same anions. In this case, receptor 2 (concentration $=6.0 \times 10^{-6} \mathrm{~mol} / \mathrm{L}$ ) in acetonitrile shows a broad emission band at $368 \mathrm{~nm}$ when excited at $278 \mathrm{~nm}$. On gradual addition of anions to the solution containing receptor 2, the fluorescence intensity is decreased to a smaller degree than that observed for $\mathbf{1}$. This indicates that the PET process is more active in $\mathbf{1}$ during complexation than in $\mathbf{2}$. The Stern-Volmer plot of $\mathbf{2}$ in Figure 5 shows the quenching behavior of different anions. Greater quenching is observed for more basic anions such as dihydrogen phosphate and fluoride. The change in the emission of $\mathbf{2}$ upon addition of

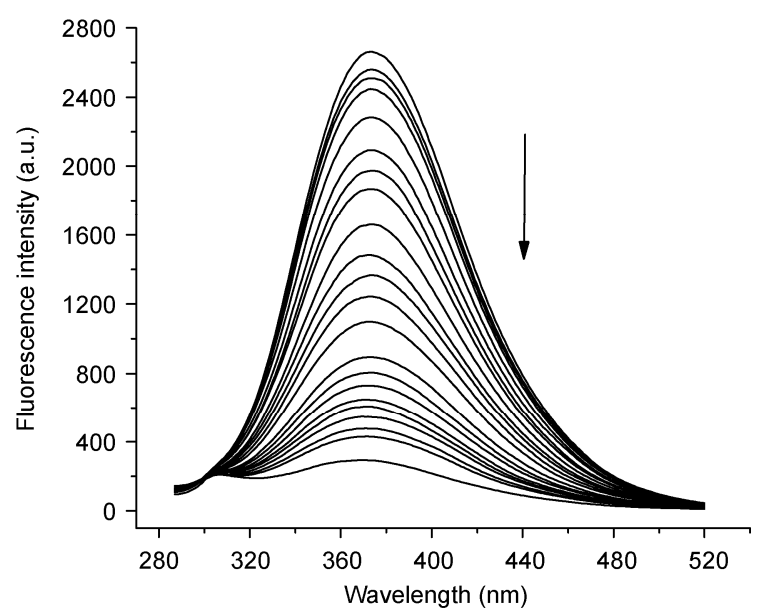

Figure 3 Changes in fluorescence spectra of 1 (concentration $=6.0 \times 10^{-6}$ $\mathrm{mol} / \mathrm{L})$ in acetonitrile upon addition of fluoride ( $0-50$ equiv.).

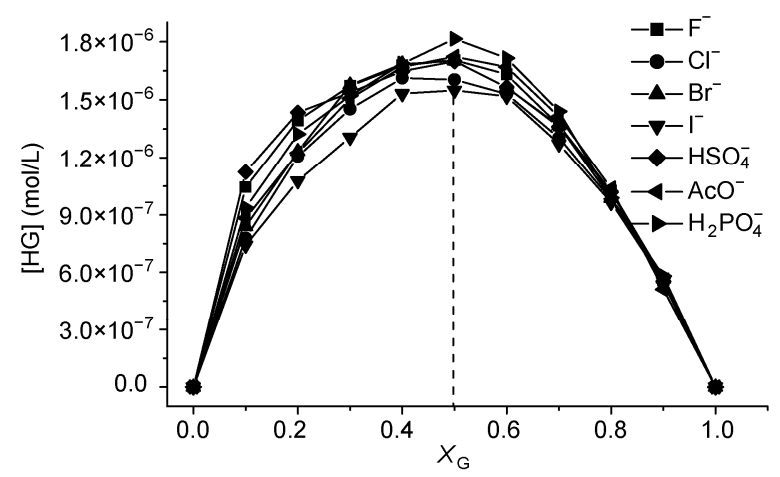

Figure 4 Fluorescence Job plot of $\mathbf{1}$ in the presence of different guest anions $(\mathrm{G}) \cdot[\mathbf{1}]+[\mathrm{G}]=6.0 \times 10^{-6} \mathrm{~mol} / \mathrm{L}$.

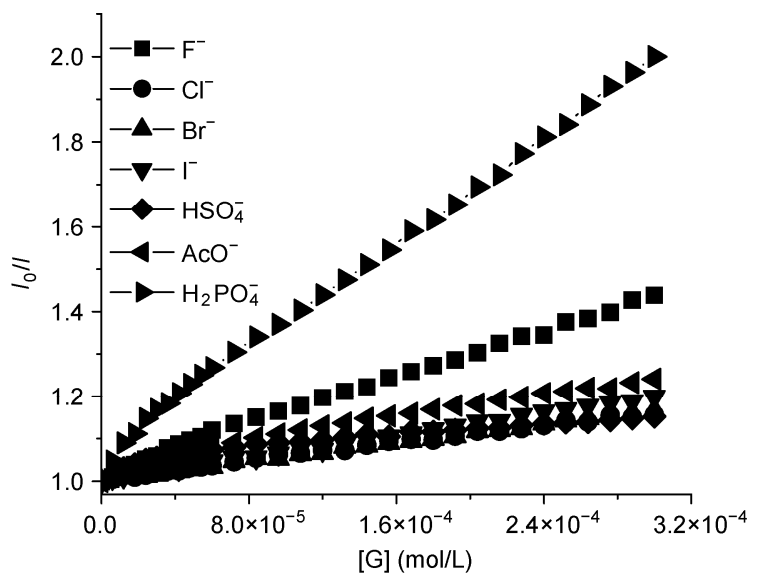

Figure 5 Stern-Volmer plot of 2 measured at $368 \mathrm{~nm}$.

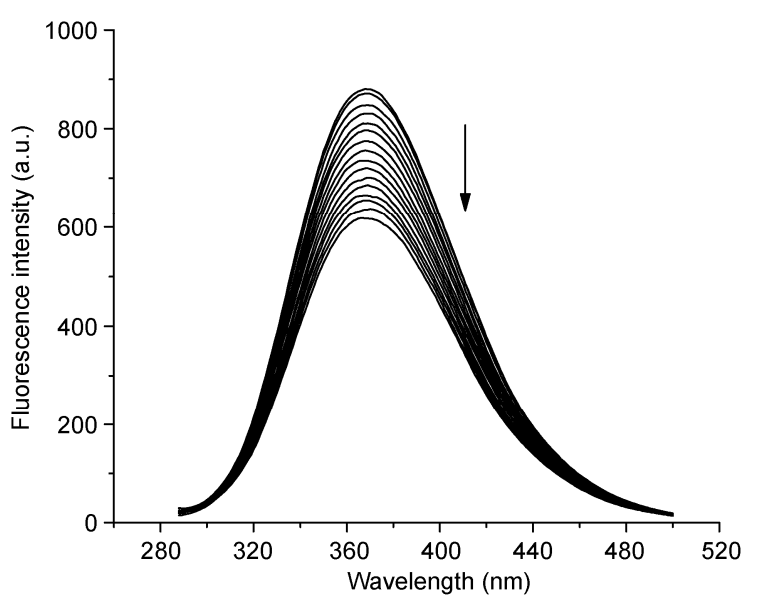

Figure 6 Changes in fluorescence spectra of 2 (concentration $=6.0 \times 10^{-6}$ $\mathrm{mol} / \mathrm{L})$ in acetonitrile upon addition of fluoride ( $0-50$ equiv.).

tetrabutylammonium fluoride is represented in Figure 6 as a representative example. The stoichiometry of the complexes was confirmed by fluorescence Job plots, which show that all anions formed $1: 1$ complexes with receptor 2 (Figure 7).

In comparison, receptor 3 (concentration $=6.0 \times 10^{-6}$ $\mathrm{mol} / \mathrm{L}$ ) shows a sharp emission band at $305 \mathrm{~nm}$ when excited at $262 \mathrm{~nm}$ in acetonitrile. On addition of increasing amounts of the same anions (up to 50 equiv.), the fluorescence intensity is increased slightly by fluoride, acetate and dihydrogen 


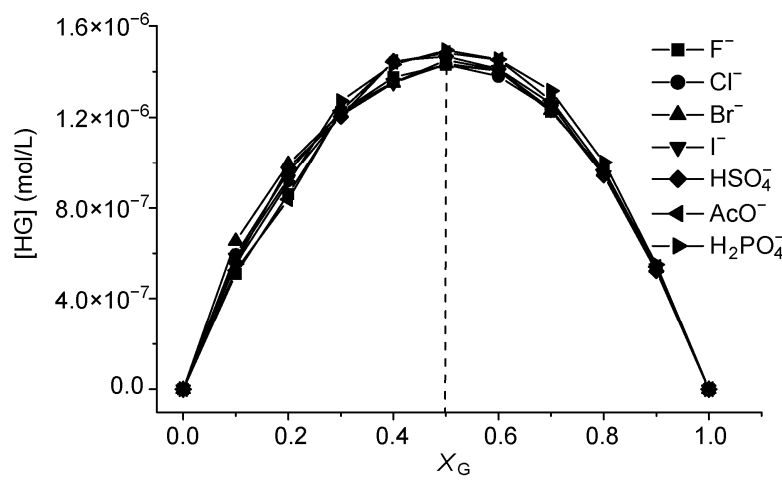

Figure 7 Fluorescence Job plot of 2 in the presence of different guest anions. $[2]+[\mathrm{G}]=6.0 \times 10^{-6} \mathrm{~mol} / \mathrm{L}$.

phosphate, and decreased slightly by chloride, bromide, iodide and hydrogen sulfate. The slight changes in intensity were insufficient to calculate the association constant reliably.

The fluorescence emission spectra show that receptor $\mathbf{1}$ possesses better recognition ability towards dihydrogen phosphate and fluoride than receptors 2 and 3. This may be because the different binding sites, and the interplay of the $(\mathrm{C}-\mathrm{H})^{+}$benzimidazolium and urea groups in receptor $\mathbf{1} \mathrm{mu}-$ tually reinforce anion recognition.

\section{$2.4 \quad$ UV-Vis study}

To further investigate the action of two different binding sites in the anion recognition process, the recognition properties of receptors 1-3 with various anions (fluoride, chloride, bromide, iodide, acetate, hydrogen sulfate, and dihydrogen phosphate as their tetrabutylammonium salts) were monitored by UV-Vis titration in DMSO.

In the absence of anions, receptors $\mathbf{1}-\mathbf{3}$ (concentration $=$ $6.0 \times 10^{-5} \mathrm{~mol} / \mathrm{L}$ ) show three characteristic absorption bands at 262, 270 and $277 \mathrm{~nm}$. When adding chloride, bromide, iodide, acetate, hydrogen sulfate, or dihydrogen phosphate respectively to a solution of $\mathbf{1}, \mathbf{2}$, or $\mathbf{3}$ in DMSO, the UV-Vis absorption spectra of $\mathbf{1}, \mathbf{2}$, or $\mathbf{3}$ do not change, which demonstrates that recognition interactions between the receptors and these anions do not occur. However, when fluoride was added to a solution of $\mathbf{1}, \mathbf{2}$, or $\mathbf{3}$ in DMSO, the UV-Vis absorption spectra changed significantly, as shown in Figure 8.

For receptor 1 (Figure 8(a)), upon addition of $0 \rightarrow 4$ equiv. of fluoride, a new broad band at $311 \mathrm{~nm}$ appears and gradually increases in intensity. Meanwhile, the intensity of the absorption peaks at 262, 270 and $277 \mathrm{~nm}$ decrease slightly, and an isosbestic point is observed at $283 \mathrm{~nm}$, which indicates that there is a balance in the solution and a stable complex has been formed between receptor $\mathbf{1}$ and fluoride. Upon addition of $4 \rightarrow 50$ equiv. fluoride, the broad band at $311 \mathrm{~nm}$ further increases in intensity, and the absorption peaks at 270 and $277 \mathrm{~nm}$ decreases significantly. The band
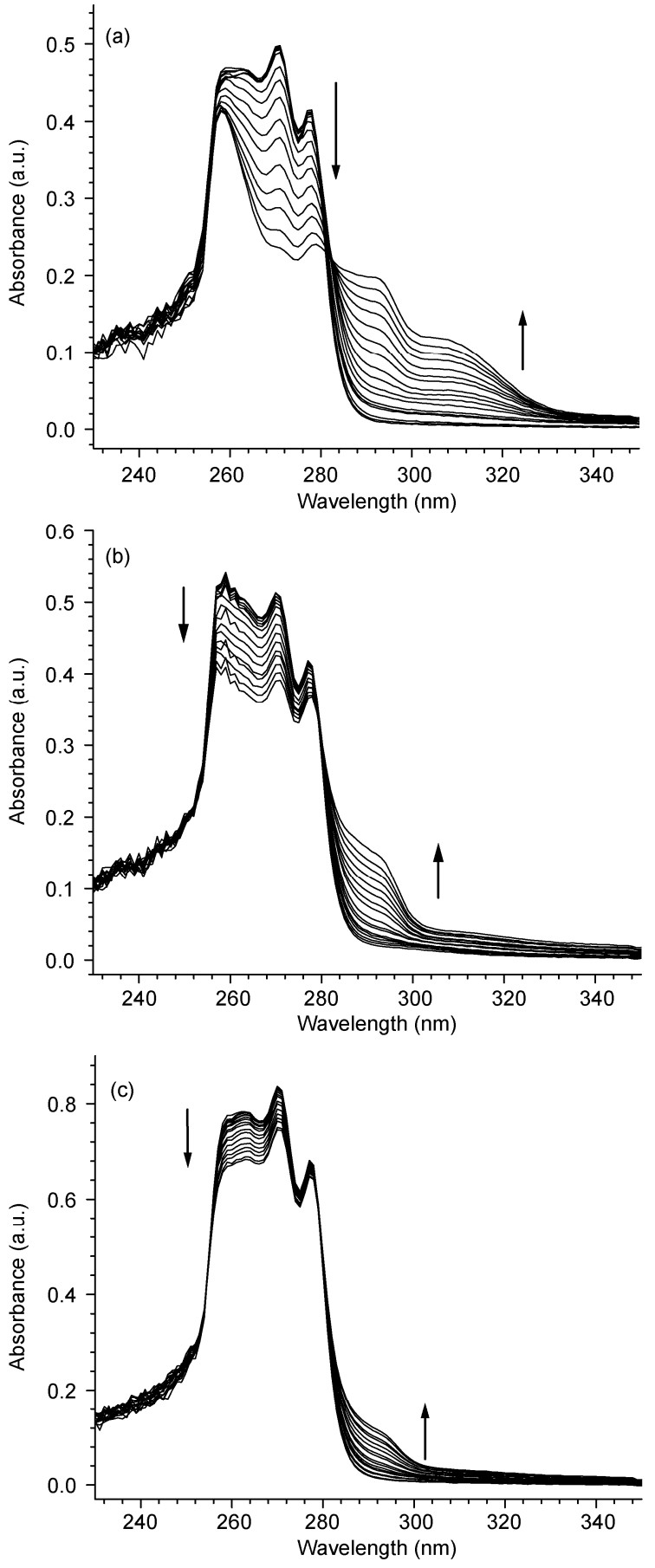

Figure 8 Changes in the UV-Vis spectra of 1-3 (concentration = $\left.5.0 \times 10^{-5} \mathrm{~mol} / \mathrm{L}\right)$ in DMSO upon addition of fluoride $(0,0.5,2,4,6,8,10$, $14,18,22,26,30,34,38,42,46$, and 50 equiv.). (a) Receptor $\mathbf{1}$, (b) receptor $\mathbf{2}$, and (c) receptor 3 .

at $262 \mathrm{~nm}$ also decreases, but with a slight blue shift to 258 $\mathrm{nm}$. This may attribute to the deprotonation of receptor $\mathbf{1}$ at higher concentrations of fluoride [64-66]. ${ }^{1} \mathrm{H}$ NMR spectroscopic studies showed similar results (Section 2.5).

Upon addition of increasing amounts of fluoride to a solution of 2 in DMSO (Figure 8(b)), a new broad band appears at $294 \mathrm{~nm}$ region that gradually increases in intensity. 
Meanwhile, the intensity of the absorption peaks at 262, 270 and $277 \mathrm{~nm}$ decrease gradually, and an isosbestic point at approximately $280 \mathrm{~nm}$ is observed, which indicates that receptor 2 and fluoride form a stable complex.

The changes in the spectra of receptor 3 (Figure 8(c)) are similar. With an increase in fluoride concentration, a new broad band appears at $294 \mathrm{~nm}$ region that gradually increases in intensity. Meanwhile, the intensity of the absorption peaks at 262 and $270 \mathrm{~nm}$ decrease gradually, while the band at $277 \mathrm{~nm}$ decreases slightly. An isosbestic point at approximately $280 \mathrm{~nm}$ is observed, which indicates that receptor $\mathbf{3}$ and fluoride form a stable complex.

Figure 9 shows the dependence of the ratio of the absorbance at 294 and $270 \mathrm{~nm}\left(A_{294 \mathrm{~nm}} / A_{270 \mathrm{~nm}}\right)$ on the concentration of fluoride. Receptor 1 shows better recognition ability of fluoride than receptors $\mathbf{2}$ and $\mathbf{3}$. We propose that the charged $(\mathrm{C}-\mathrm{H})^{+}$benzimidazolium moiety and urea group have a synergistic effect in anion recognition.

\section{$2.5 \quad{ }^{1}$ H NMR spectroscopic study}

${ }^{1} \mathrm{H}$ NMR spectroscopy has been widely used to investigate receptor-substrate interactions and can provide details of the interaction between receptors and anions [67]. As shown in Figure 10, upon addition of different anions $\left(\mathrm{H}_{2} \mathrm{PO}_{4}^{-}, \mathrm{F}^{-}, \mathrm{Cl}^{-}\right.$, $\mathrm{Br}^{-}$and $\mathrm{I}^{-}$as their tetrabutylammonium salts) to a solution of receptor 1 in DMSO- $d_{6}$ (with a composition of $[\mathbf{1}] /[\mathrm{G}]=$ $1: 1)$, downfield shifts of $\Delta \delta \approx 0.11,0.10,0.03,0.03$, and 0.00 , respectively, were observed for the $(\mathrm{C}-\mathrm{H})^{+}$benzimidazolium proton (assigned as $\mathrm{Ha}$ ). Upon addition of $\mathrm{H}_{2} \mathrm{PO}_{4}^{-}$ and $\mathrm{F}^{-}$, the signals of the urea protons (assigned as $\mathrm{Hb}$ and $\mathrm{Hc}$ ) in 1 also moved downfield $\Delta \delta \approx 0.12,0.04$ and 0.10 , 0.03 , respectively. No changes were observed for the other anions.

To further investigate the nature of the host-guest interactions, ${ }^{1} \mathrm{H}$ NMR titration experiments were conducted in DMSO- $d_{6}$. Figure 11 shows partial ${ }^{1} \mathrm{H}$ NMR spectra of receptor 1, highlighting the change of $\mathrm{Ha}, \mathrm{Hb}$ and $\mathrm{Hc}$ upon

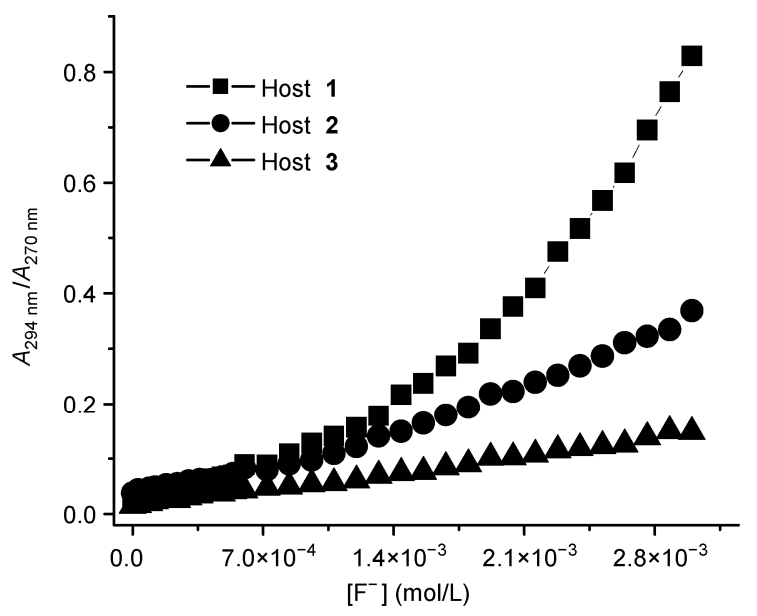

Figure $9 A_{294 \mathrm{~nm}} / A_{270 \mathrm{~nm}}$ as a function of fluoride concentration for receptors 1-3.
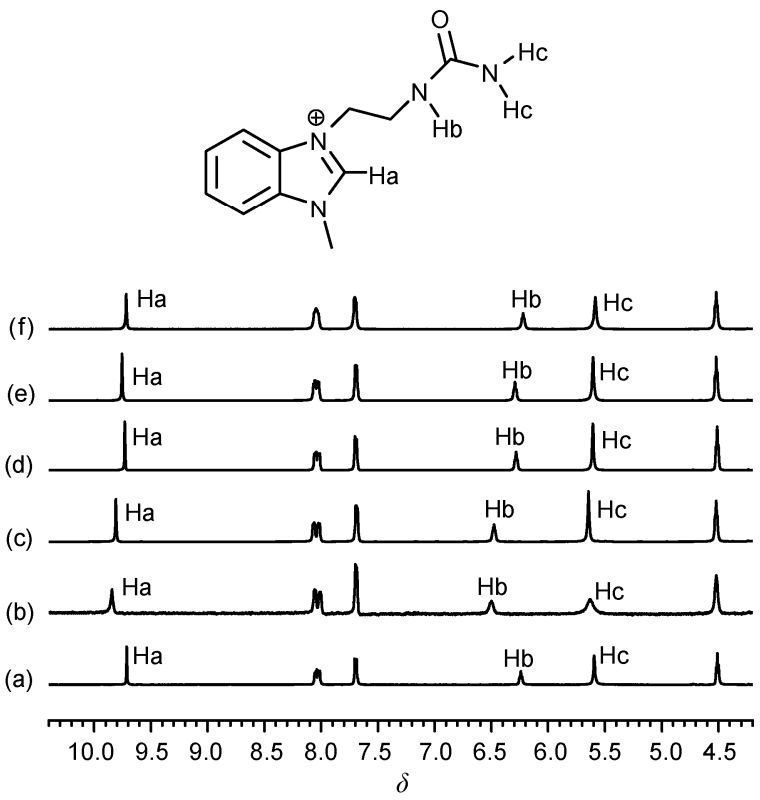

Figure 10 Partial ${ }^{1} \mathrm{H}$ NMR spectra of 1 (concentration $=6.0 \times 10^{-3} \mathrm{~mol} / \mathrm{L}$ ) in DMSO- $d_{6}$ with different anions. (a) Receptor 1 only; (b) $1: 1$ complex with dihydrogen phosphate; (c) 1:1 complex with fluoride; (d) 1:1 complex with chloride; (e) $1: 1$ complex with bromide; (f) $1: 1$ complex with iodide.

addition of fluoride. It is obvious that upon addition of increasing amounts of fluoride, the signal of the terminal urea proton Hc only shows a minor downfield shift. The Ha signal shifts downfield gradually and the signal broadens, which implies interaction of the fluoride anion with Ha via favorable ionic $(\mathrm{C}-\mathrm{H})^{+} \ldots \mathrm{F}^{-}$hydrogen bonding $[68,69]$. The $\mathrm{Hb}$ signal from the internal urea proton shifts downfield at low ratios of $\mathrm{F}^{-}$to $\mathbf{1}$, whereas at higher ratios of $\mathrm{F}^{-}$to $\mathbf{1}$ the signal broadens and decreases in intensity. At the same time, a new signal at $16.2 \mathrm{ppm}$ appears, which is ascribed to the proton of $\left[\mathrm{HF}_{2}\right]^{-}[23,70,71]$. These observations suggest that the fluoride anion and urea protons form $\mathrm{N}-\mathrm{H} \cdots \mathrm{F}^{-}$hydrogen bonds at low concentrations of $\mathrm{F}^{-}$, while at higher concentrations of $\mathrm{F}^{-}$, deprotonation of $\mathrm{Hb}$ occurs.

Likewise, a partial ${ }^{1} \mathrm{H}$ NMR spectra of receptor 2 highlighting changes of the $(\mathrm{C}-\mathrm{H})^{+}$benzimidazolium proton upon addition of fluoride are shown in Figure 12. It was observed that the signal from Ha shift downfield like that of receptor 1, which implies a complex between receptor $\mathbf{2}$ and $\mathrm{F}^{-}$has formed through ionic $(\mathrm{C}-\mathrm{H})^{+} \cdots \mathrm{F}^{-}$hydrogen bonding.

Partial ${ }^{1} \mathrm{H}$ NMR spectra of receptor 3 revealing changes upon addition of fluoride are presented in Figure 13. At low ratios of $\mathrm{F}^{-}$to $\mathbf{3}$, the signal for the internal urea proton $\mathrm{Ha}$ shifts upfield, the terminal urea proton Hc only shows a minor upfield shift, and the majority of signals on the benzimidazole rings shift upfield. At higher ratios of $\mathrm{F}^{-}$to 3 , the signals of all protons remained unchanged, and a new signal at 12.8 appears because of the $\left[\mathrm{HF}_{2}\right]^{-}$. These observations indicate deprotonation, which increases the shielding effect and caused the general upfield shift of the protons [72,73]. 

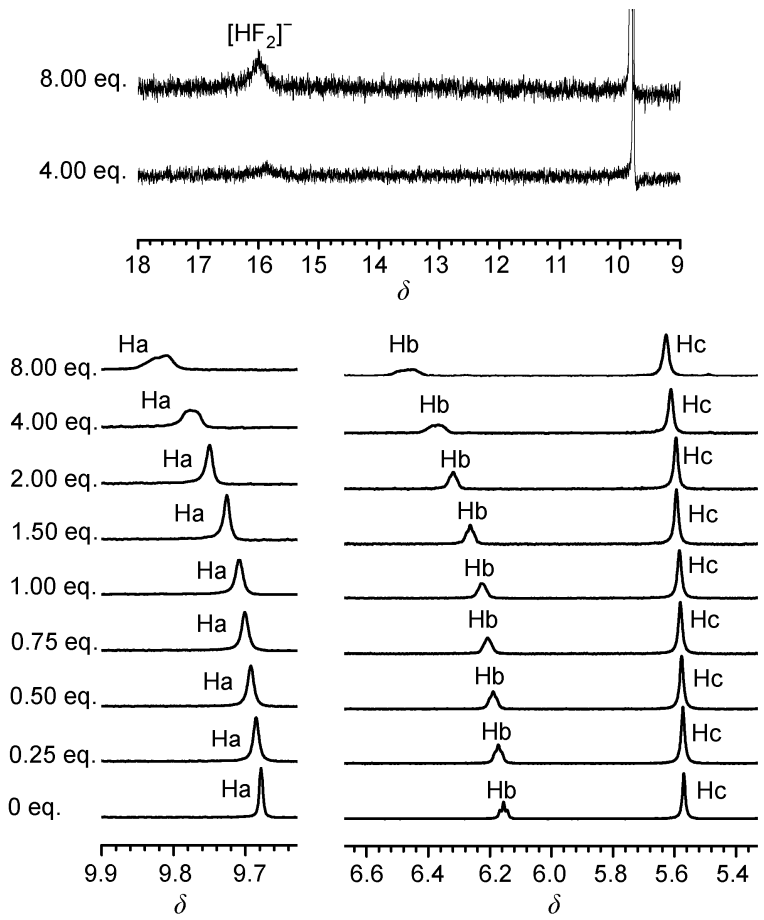

Figure 11 Partial ${ }^{1} \mathrm{H}$ NMR spectra of 1 (concnetration $=6.0 \times 10^{-3} \mathrm{~mol} / \mathrm{L}$ ) in DMSO- $d_{6}$ in the absence and presence of $0.25,0.50,0.75,1.00,1.50$, $2.00,4.00$ and 8.00 equiv. of fluoride.

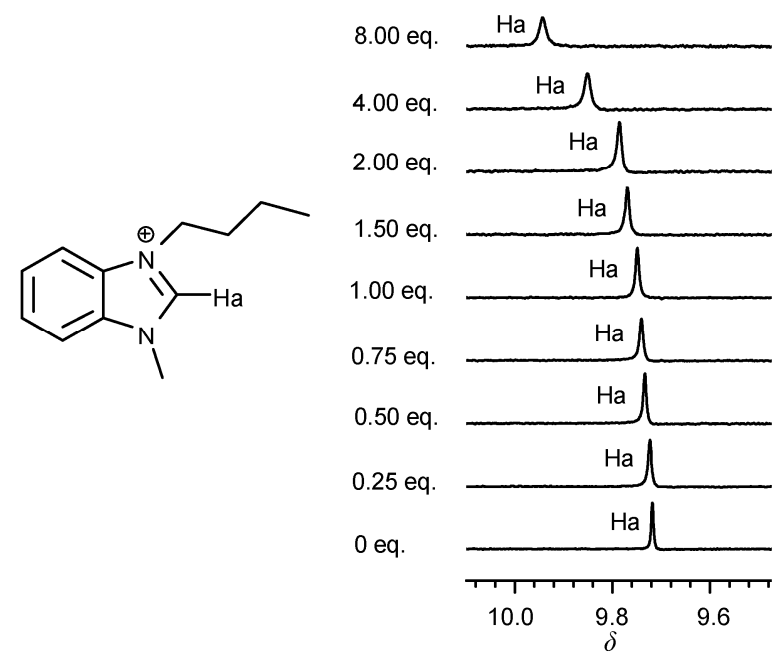

Figure 12 Partial ${ }^{1} \mathrm{H}$ NMR spectra of 2 (concentration $=6.0 \times 10^{-3} \mathrm{~mol} / \mathrm{L}$ ) in DMSO- $d_{6}$ in the absence and presence of $0.25,0.50,0.75,1.00,1.50$, $2.00,4.00$ and 8.00 equiv. of fluoride.

From these results, the possible hydrogen bonding modes of receptors 1 with fluoride at low concentrations of $\mathrm{F}^{-}$are shown in Figure 14. The $(\mathrm{C}-\mathrm{H})^{+}$benzimidazolium moiety and urea group of receptor $\mathbf{1}$ bind to fluoride as hydrogen donors to form hydrogen bonds $\mathrm{N}-\mathrm{H} \cdots \mathrm{F}^{-}$and $(\mathrm{C}-\mathrm{H})^{+} \cdots \mathrm{F}^{-}$, respectively.

\subsection{Binding constant determination}

The change of fluorescence intensity as a function of guest concentration allows binding constants to be calculated. For<smiles>O=C(N(P)P)N(P)CCn1cnc2ccccc21</smiles>

$\left[\mathrm{HF}_{2}\right]^{-}$
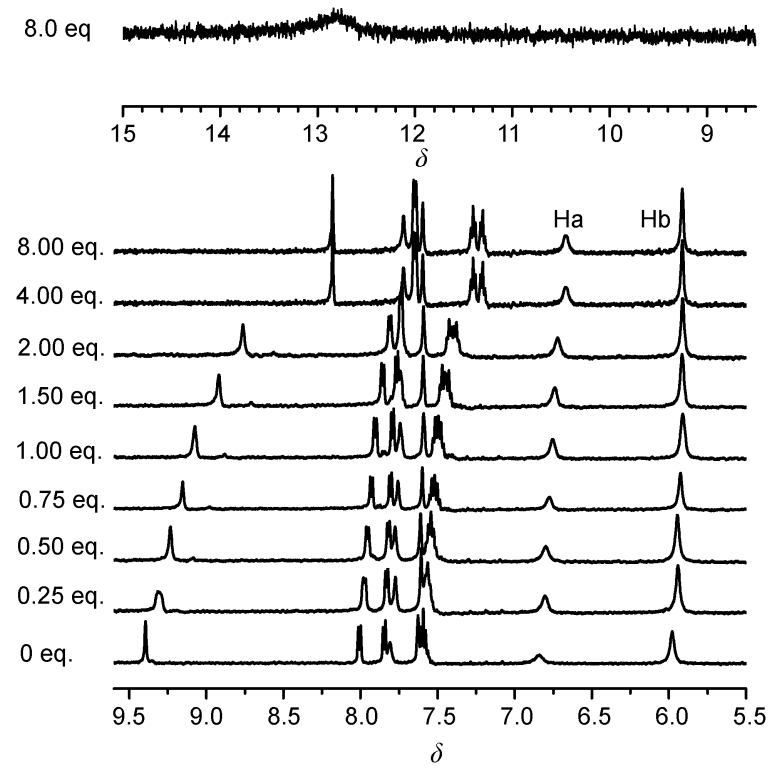

Figure 13 Partial ${ }^{1} \mathrm{H}$ NMR spectra of 3 (concentration $=6.0 \times 10^{-3} \mathrm{~mol} / \mathrm{L}$ ) in DMSO- $d_{6}$ in the absence and presence of $0.25,0.50,0.75,1.00,1.50$, $2.00,4.00$ and 8.00 equiv. of fluoride.

a complex with 1:1 stoichiometry, the following relation applies [74]:

$$
\begin{aligned}
I= & I_{0}+\left(I_{\mathrm{lim}}-I_{0}\right) / 2 C_{\mathrm{H}}\left\{C_{\mathrm{H}}+C_{\mathrm{G}}+1 / K-\right. \\
& {\left.\left[\left(C_{\mathrm{H}}+C_{\mathrm{G}}+1 / K\right)^{2}-4 C_{\mathrm{H}} C_{\mathrm{G}}\right]^{1 / 2}\right\}, }
\end{aligned}
$$

where $I$ is the fluorescence intensity, $I_{0}$ is the intensity of pure host, $C_{\mathrm{H}}$ and $C_{\mathrm{G}}$ are the corresponding concentrations of host and anionic guest, respectively, and $K$ is the binding constant. $K$ and correlation coefficient $R^{2}$ obtained by a nonlinear least-square analysis of $I$ versus $C_{\mathrm{H}}$ and $C_{\mathrm{G}}$ are presented in Table 1. The result of non-linear curve fitting confirms that a $1: 1$ stoichiometric complex has been formed between host and guest [75].

From Table 1, we can see that: (1) the anion affinity constants of receptor 1 are in the order: $\mathrm{H}_{2} \mathrm{PO}_{4}^{-}>\mathrm{F}^{-}>\mathrm{AcO}^{-}>$ $\mathrm{Cl}^{-}>\mathrm{Br}^{-}>\mathrm{HSO}_{4}^{-} \approx \mathrm{I}^{-}$, while that of receptor 2 are in the order: $\mathrm{F}^{-}>\mathrm{H}_{2} \mathrm{PO}_{4}^{-}>\mathrm{AcO}^{-}>\mathrm{C}^{-} \approx \mathrm{Br}^{-} \approx \mathrm{HSO}_{4}^{-} \approx \mathrm{I}^{-}$. (2) Receptor 1 shows higher binding constant values for anions

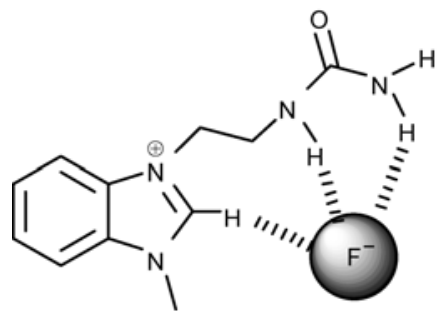

Figure 14 Possible hydrogen bonding modes of complex of 1 with $\mathrm{F}^{-}$(at low concentrations of $\mathrm{F}^{-}$). 
Table 1 Binding constants of receptors 1 and $\mathbf{2}$ with different anions obtained by analysis of fluorescence intensity

\begin{tabular}{lccc}
\hline \multirow{2}{*}{ Guests } & Receptor 1 & \multicolumn{2}{c}{ Receptor 2 } \\
\cline { 2 - 4 } & $K_{\mathrm{a}}(\mathrm{L} / \mathrm{mol})$ & $R^{2}$ & $K_{\mathrm{a}}(\mathrm{L} / \mathrm{mol})$ \\
\hline $\mathrm{F}^{-}$ & $(1.75 \pm 0.07) \times 10^{5}$ & 0.9992 & $(3.33 \pm 0.21) \times 10^{4}$ \\
$\mathrm{Cl}^{-}$ & $(2.82 \pm 0.18) \times 10^{3}$ & 0.9996 & $(1.62 \pm 0.17) \times 10^{3}$ \\
$\mathrm{Br}^{-}$ & $(2.56 \pm 0.17) \times 10^{3}$ & 0.9970 & $(0.96 \pm 0.13) \times 10^{3}$ \\
$\mathrm{I}^{-}$ & $(1.23 \pm 0.13) \times 10^{3}$ & 0.9968 & $(1.11 \pm 0.15) \times 10^{3}$ \\
$\mathrm{HSO}_{4}^{-}$ & $(1.57 \pm 0.16) \times 10^{3}$ & 0.9964 & $(1.16 \pm 0.26) \times 10^{3}$ \\
$\mathrm{AcO}^{-}$ & $(1.44 \pm 0.02) \times 10^{5}$ & 0.9991 & $(5.12 \pm 0.24) \times 10^{3}$ \\
$\mathrm{H}_{2} \mathrm{PO}_{4}^{-}$ & $(3.06 \pm 0.33) \times 10^{5}$ & 0.9963 & 0.9956 \\
\hline
\end{tabular}

than 2. This indicates that the cooperative action of benzimidazolium and urea groups in binding anions by multiple interactions is an important factor for efficient recognition. The incorporation of two functional groups for anion binding effectively enhances selectivity in anion recognition and the stability of the resultant complex.

\section{Conclusions}

In summary, a series of benzimidazolium-based receptors 1-3 were prepared and characterized. Directed conventional hydrogen bonds $(\mathrm{N}-\mathrm{H} \cdots \mathrm{X})$, unconventional hydrogen bonds $\left[(\mathrm{C}-\mathrm{H})^{+} \cdots \mathrm{X}\right]$, and charge-charge interactions allowed $\mathbf{1}$ to bind fluoride anions more effectively than $\mathbf{2}$ and $\mathbf{3}$. Hence, the charged $(\mathrm{C}-\mathrm{H})^{+}$benzimidazolium moiety and urea group have a synergistic effect in anion recognition.

This work was supported by the National Natural Science Foundation of China (21072061) and the Shanghai Leading Academic Discipline Project (B409).

1 Chen Y, Liu Y. Cyclodextrin-based bioactive supramolecular assemblies. Chem Soc Rev, 2010, 39: 495-505

2 Steed J W. Coordination and organometallic compounds as anion receptors and sensors. Chem Soc Rev, 2009, 38: 506-519

3 Caltagirone C, Gale P A. Anion receptor chemistry: Highlights from 2007. Chem Soc Rev, 2009, 38: 520-563

4 Kubik S. Amino acid containing anion receptors. Chem Soc Rev, 2009, 38: 585-605

5 Gale P A, García-Garrido S E, Garric J. Anion receptors based on organic frameworks: Highlights from 2005 and 2006. Chem Soc Rev, 2008, 37: 151-190

6 Beer P D, Gale P A. Anion recognition and sensing: The state of art and future perspectives. Angew Chem Int Ed, 2001, 40: 486-516

7 Beer P D, Hayes E J. Transition metal and organometallic anioncomplexation agents. Coord Chem Rev, 2003, 240: 167-189

8 Tobey S L, Anslyn E V. Determination of inorganic phosphate in serum and saliva using a synthetic receptor. Org Lett, 2003, 5: 2029-2031

$9 \mathrm{Xu} \mathrm{Z} \mathrm{C,} \mathrm{Kim} \mathrm{S,} \mathrm{Lee} \mathrm{K} \mathrm{H,} \mathrm{et} \mathrm{al.} \mathrm{A} \mathrm{highly} \mathrm{selective} \mathrm{fluorescent}$ chemosensor for dihydrogen phosphate via unique excimer formation and PET mechanism. Tetrahedron Lett, 2007, 48: 3797-3800

10 Cho E J, Moon J W, Ko S W, et al. A new fluoride selective fluorescent as well as chromogenic chemosensor containing a naphthalene urea derivative. J Am Chem Soc, 2003, 125: 12376-12377

11 Jun E J, Swamy K M K, Bang H, et al. Anthracene derivatives bearing thiourea group as fluoride selective fluorescent and colorimetric chemosensors. Tetrahedron Lett, 2006, 47: 3103-3106

12 Cametti M, Rissanen K. Recognition and sensing of fluoride anion.
Chem Commun, 2009, 20: 2809-2829

13 Gunnlaugsson T, Davis A P, O'Brien J E, et al. Fluorescent sensing of pyrophosphate and bis-carboxylates with charge neutral PET chemosensors. Org Lett, 2002, 4: 2449-2452

14 Kral V, Andrievsky A, Sessler J L. A covalently linked sapphyrin dimer: A new receptor for dicarboxylate anions. J Am Chem Soc, 1995, 117: 2953-2954

15 Ray J K, Gupta S, Pan D, et al. Molecular recognition: Studies on the synthesis of some bis thiophene carboxamide derivatives as ditopic receptors for long chain dicarboxylic acids. Tetrahedron, 2001, 57: 7213-7219

16 Ghosh K, Masanta G, Chattopadhyay A P. Anthracene-based ureidopyridyl fluororeceptor for dicarboxylates. Tetrahedron Lett, 2007, 48: 6129-6132

17 Kang S O, Powell D, Dayand V W, et al. Trapped bifluoride. Angew Chem Int Ed, 2006, 45: 1921-1925

18 Kang S O, Powell D, Bowman-James K. Anion binding motifs: Topicity and charge in amidocryptands. J Am Chem Soc, 2005, 127: 13478-13479

19 Gale P A. Structural and molecular recognition studies with acyclic anion receptors. Acc Chem Res, 2006, 39: 465-475

20 Wang T, Bai Y, Ma L, et al. Synthesis and characterization of indolocarbazole-quinoxalines with flat rigid structure for sensing fluoride and acetate anions. Org Biomol Chem, 2008, 6: 1751-1755

21 Gale P A. Synthetic indole, carbazole, biindole and indolocarbazolebased receptors: Applications in anion complexation and sensing. Chem Commun, 2008, 38: 4525-4540

22 Yoo J, Kim M S, Hong S, et al. Selective sensing of anions with calix [4]pyrroles strapped with chromogenic dipyrrolylquinoxalines. J Org Chem, 2009, 74: 1065-1069

23 Jia C D, Wu B, Liang J J, et al. A colorimetric and ratiometric fluorescent chemosensor for fluoride based on proton transfer. J Fluoresc, 2010, 20: 291-297

24 Jose D A, Singh A, Das A, et al. A density functional study towards the preferential binding of anions to urea and thiourea. Tetrahedron Lett, 2007, 48: 3695-3698

25 Perez-Casas C, Yatsimirsky A K. Detailing hydrogen bonding and deprotonation equilibria between anions and urea/thiourea derivatives. J Org Chem, 2008, 73: 2275-2284

26 Dukeand R M, Gunnlaugsson T. Selective fluorescent PET sensing of fluoride $\left(\mathrm{F}^{-}\right)$using naphthalimide thiourea and urea conjugates. Tetrahedron Lett, 2007, 48: 8043-8047

27 Lee G W, Singh N, Jang D O. Benzimidazole and thiourea conjugated fluorescent hybrid receptor for selective recognition of $\mathrm{PO}_{4}{ }^{3-}$. Tetrahedron Lett, 2008, 49: 1952-1956

28 Devaraj S, Saravanakumar D, Kandaswamy M. Dual chemosensing properties of new anthraquinone-based receptors toward fluoride ions. Tetrahedron Lett, 2007, 48: 3077-3081

29 Luxami V, Kumar S. Colorimetric and ratiometric fluorescence sensing of fluoride ions based on competitive intra and intermolecular proton transfer. Tetrahedron Lett, 2007, 48: 3083-3087

30 Wu J S, Zhou J H, Wang P F, et al. New fluorescent chemosensor based on exciplex signaling mechanism. Org Lett, 2005, 7: 2133-2136

31 Cooper C R, Spencer N, James T D. Selective fluorescence detection of fluoride using boronic acids. Chem Commun, 1998, 13: 1365-1366 
32 Yamaguchi S, Akiyama S, Tamao K. Colorimetric fluoride ion sensing by boron-containing $\pi$-electron systems. J Am Chem Soc, 2001, 123: 11372-11375

33 Kubo Y, Ishida T, Minami T, et al. Highly selective fluoride ion detection based on a fluorescent alizarin-o-aminomethylphenylboronic acid ensemble in aqueous MeOH solution. Chem Lett, 2006, 35: 996-997

34 Hossain M A, L1inares J M, Mason S, et al. Parallels in cation and anion coordination: A new class of cascade complexes. Angew Chem Int Ed, 2002, 41: 2335-2338

35 Brooks S J, Gale P A, Light M E. Anion-binding modes in a macrocyclic amidourea. Chem Commun, 2006, 4344-4346

36 Roth A, Buchholz A, Rudolph M, et al. Directed synthesis of a heterobimetallic complex based on a novel unsymmetric double schiff base ligand: Preparation, characterization, reactivity and structures of hetero and homobimetallic nickel(II) and zinc(II) complexes. Chem Eur J, 2008, 14: 1571-1583

37 Wang D X, Zheng Q Y, Wang Q Q, et al. Halide recognition by tetraoxacalix[2] arene[2]triazine receptors: Concurrent noncovalent halide- $\pi$ and Lone-pair- $\pi$ interactions in host-halide-water ternary complexes. Angew Chem Int Ed, 2008, 47: 7485-7488

38 Raker J, Glass T E. Selectivity via cooperative interactions: Detection of dicarboxylates in water by a pinwheel chemosensor. J Org Chem, 2002, 67: 6113-6116

39 Blondeau P, Segura M, Perez-Fernandez R, et al. Molecular recognition of oxoanions based on guanidinium receptors. Chem Soc Rev, 2007, 36: 198-210

40 Wallace K J, Belcher W J, Turner D R, et al. Slow anion exchange, conformational equilibria, and fluorescent sensing in Venus flytrap aminopyridinium-based anion hosts. J Am Chem Soc, 2003, 125: 9699-9715

41 Filby M H, Dickson S J, Zaccheroni N, et al. Induced fit interanion discrimination by binding-induced excimer formation. J Am Chem Soc, 2008, 130: 4105-4113

42 Swinburne A N, Paterson M J, Fischer K H, et al. Colourimetric carboxylate anion sensors derived from viologen-based receptors. Chem Eur J, 2010, 16: 1480-1492

43 Amendola V, Boiocchi M, Fabbrizzi L, et al. What anions do inside a receptor's cavity: A trifurcate anion receptor providing both electrostatic and hydrogen-bonding interactions. Chem Eur J, 2005, 11: 5648-5660

44 Ghosh K, Sarkar A R, Patra A. Pyridinium amide-based simple synthetic receptor for selective recognition of dihydrogenphosphate. Tetrahedron Lett, 2009, 50: 6557-6561

45 In S, Kang J. Acetate-selective anion receptor with methylenebridged bis-imidazolium rings. J Inclusion Phenom Macrocyclic Chem, 2006, 54: 129-132

46 Chahar M, Upreti S, Pandey P S. Anion recognition by bisimidazolium and bisbenzimidazolium cholapods. Tetrahedron, 2007, 63: 171-176

47 Su X Y, Luo K, Xiang Q X, et al. Enantioselective recognitions of chiral molecular tweezers containing imidazoliums for amino acids. Chirality, 2009, 21: 539-546

48 Lu Q S, Dong L, Zhang J, et al. Imidazolium-functionalized BINOL as a multifunctional receptor for chromogenic and chiral anion recognition. Org Lett, 2009, 11: 669-672

49 Su D D, Nu H T, Wang Y, et al. Imidazolium-based fluorescent chemosensor for highly selective recognition of dihydrogen phosphate. Chem J Chin Univ, 2010, 31: 714-717

50 Gong H Y, Rambo B M, Karnas E, et al. Environmentally responsive threading, dethreading, and fixation of anion-induced pseudorotaxanes. J Am Chem Soc, 2011, 133: 1526-1533

51 Bai Y, Zhang B G, Xu J, et al. Conformational switching fluorescent chemosensor for chloride anion. New J Chem, 2005, 29: 777-779

52 Wong W W H, Vickers M S, Cowley A R, et al. Tetrakis (imidazolium) macrocyclic receptors for anion binding. Org Biomol Chem, 2005, 3: 4201-4208
53 Khatri V K, Upreti S, Pandey P S. Novel bile acid-based cyclic bisimidazolium receptors for anion recognition. Org Lett, 2006, 8: 1755-1758

54 Khatri V K, Chahar M, Pavani K, et al. Bile acid-based cyclic bisbenzimidazolium receptors for anion recognition: Highly improved receptors for fluoride and chloride ions. J Org Chem, 2007, 72 10224-10226

55 Yoon J, Kim S K, Singh N J, et al. Imidazolium receptors for the recognition of anions. Chem Soc Rev, 2006, 35: 355-360

$56 \mathrm{Xu} \mathrm{Z} \mathrm{C,} \mathrm{Kim} \mathrm{S} \mathrm{K,} \mathrm{Yoon} \mathrm{J.} \mathrm{Revisit} \mathrm{to} \mathrm{imidazolium} \mathrm{receptors} \mathrm{for} \mathrm{the}$ recognition of anions: Highlighted research during 2006-2009. Chem Soc Rev, 2010, 39: 1457-1466

57 Ghosh K, Saha I. Anthracene-based ortho-phenylenediamine clefts for sensing carboxylates. Tetrahedron Lett, 2008, 49: 4591-4595

58 Ghosh K, Saha I, Patra A. Design and synthesis of an ortho-phenylenediamine-based open cleft: A selective fluorescent chemosensor for dihydrogen phosphate. Tetrahedron Lett, 2009, 50: 2392-2397

$59 \mathrm{Xu} \mathrm{Z} \mathrm{C,} \mathrm{Kim} \mathrm{S} \mathrm{K,} \mathrm{Han} \mathrm{S} \mathrm{J,} \mathrm{et} \mathrm{al.} \mathrm{Ratiometric} \mathrm{fluorescence} \mathrm{sensing} \mathrm{of}$ fluoride ions by an asymmetric bidentate receptor containing a boronic acid and imidazolium group. Eur J Org Chem, 2009, 18: 3058-3065

60 Sheldrick G M. SHELXTL. Version 5.1. Madison, WI: Bruker Analytical X-ray Instruments Inc., 1998

61 Singh N J, Jun E J, Chellappan K, et al. Quinoxaline-imidazolium receptors for unique sensing of pyrophosphate and acetate by charge transfer. Org Lett, 2007, 9: 485-488

62 Willans C E, Anderson K M, Potts L C, et al. Allosteric effects in a tetrapodal imidazolium-derived calix[4]arene anion receptor. Org Biomol Chem, 2009, 7: 2756-2760

63 Lakowicz J R. Principles of Fluorescence Spectroscopy. 3rd ed. Berlin Heidelberg: Springer-Verlag, 2006. 282-283

64 Liu W X, Jiang Y B. Intramolecular hydrogen bonding and anion binding of $N$-benzamido- $N$ '-benzoylthioureas. J Org Chem, 2008, 73: 1121-1127

65 Jose D A, Kumar D K, Ganguly B, et al. Efficient and simple colorimetric fluoride ion sensor based on receptors having urea and thiourea binding sites. Org Lett, 2004, 6: 3445-3448

66 Zhang Y M, Wang Y L, Lin Q, et al. Synthesis of 5-aryl-2-furoyl thiosemicarbazides and anion recognition in aqueous media. Chin $\mathrm{J}$ Org Chem, 2009, 29: 575-579

67 Liu S Y, He Y B, Wu J L, et al. Calix[4]arenes containing thiourea and amide moieties: Neutral receptors towards $\alpha, \omega$-dicarboxylate anions. Org Biomol Chem, 2004, 2: 1582-1586

68 Kim S K, Seo D, Han S J, et al. A new imidazolium acridine derivative as fluorescent chemosensor for pyrophosphate and dihydrogen phosphate. Tetrahedron, 2008, 64: 6402-6405

69 Kim S K, Singh N J, Kwon J, et al. Fluorescent imidazolium receptors for the recognition of pyrophosphate. Tetrahedron, 2006, 64: 6065-6072

70 Descalzo A B, Rurack K, Weisshoff H, et al. Rational design of a chromo and fluorogenic hybrid chemosensor material for the detection of long-chain carboxylates. J Am Chem Soc, 2005, 127: 184-200

71 Sun H, DiMagno S G. Anhydrous tetrabutylammonium fluoride. J Am Chem Soc, 2005, 127: 2050-2051

72 Boiocchi M, Boca L D, Esteban-Gómez D, et al. Anion-induced urea deprotonation. Chem Eur J, 2005, 11: 3097-3104

73 Pérez-Casas C, Yatsimirsky A K. Detailing hydrogen bonding and deprotonation equilibria between anions and urea/thiourea derivatives. J Org Chem, 2008, 73: 2275-2284

74 Valeur B, Pouget J, Bourson J, et al. Tuning of photoinduced energy transfer in a bichromophoric coumarin supermolecule by cation binding. J Phys Chem, 1992, 96: 6545-6549

75 Bourson J, Pouget J, Valeur B, et al. Ion-responsive fluorescent compounds 4: Effect of cation binding on the photophysical properties of a coumarin linked to monoaza and diaza crown ethers. J Phys Chem, 1993, 97: 4552-4557

Open Access This article is distributed under the terms of the Creative Commons Attribution License which permits any use, distribution, and reproduction in any medium, provided the original author(s) and source are credited. 